\title{
Pemutuan Belimbing Manis (averrhoa carambola l.) Menggunakan Pengolahan Citra Digital Berbasis Jaringan Syaraf Tiruan
}

\section{(Starfruit (Averrhoa carambola L.) Grading using Digital Image Processing Based on Artificial Neural Network)}

\author{
Moh Ruky Nur Firmansyah ${ }^{1 *}$, Dedy Wirawan Soedibyo ${ }^{2)}$, dan Sri Wahyuningsih ${ }^{3)}$ \\ ${ }^{1 *}$ Program Studi Teknik Pertanian Universitas Jember) \\ 2) Program Studi Teknik Pertanian Universitas Jember) \\ 3) Program Studi Teknik Pertanian Universitas Jember) \\ *) email korespondensi: ruckybrew@ gmail.com
}

\begin{abstract}
ABSTRAK
Penanganan pasca panen belimbing perlu dilakukan agar kualitas buah tetap terjaga, salah satu contohnya adalah melakukan pemutuan sebelum proses penjualan. Pemutuan buah belimbing di Indonesia umumnya masih dilakukan dengan cara manual yang memiliki keterbatasan dari segi waktu, tenaga dan penilaian (subjektif). Pengolahan citra (image processing) dan jaringan syaraf tiruan (JST) dapat dijadikan sebagai salah satu metode penanganan pasca panen yang dapat membantu memutukan buah belimbing lebih seragam dan efektif. Penelitian ini bertujuan untuk menyusun dan menghasilkan sebuah program pengolahan citra pemutuan buah belimbing serta mengetahui tingkat keakuratan program tersebut dalam pendugaan mutu. Sampel bahan yang digunakan yaitu belimbing dengan kelas mutu A, B, C dan Reject yang dimutukan secara manual terlebih dahulu. Total sampel 200 buah, terdiri atas 160 buah (40 buah per kelas mutu) untuk training dan 40 buah (10 per kelas mutu) untuk testing. Tahapan penelitian meliputi image aquisition, pengambilan gambar citra, penentuan variabel mutu citra, pembuatan program pengolahan citra, ektraksi citra, analisis statistik dan pembuatan grafik boxplot, penentuan input JST, penentuan variasi arsitektur JST, training semua variasi JST, simulasi data testing dengan propagasi maju, penentuan variasi terbaik, integrasi model JST dengan program pengolahan citra, serta validasi program. Hasil penelitian menunjukkan variasi JST terbaik untuk menyusun program pemutuan belimbing adalah variasi dengan 10 node hidden layer dan 7 input variabel (area, tinggi, perimeter, area cacat, indeks warna $\mathrm{R}, \mathrm{G}$ dan B). Hasil validasi menunjukkan, program pemutuan belimbing memiliki tingkat akurasi dalam menduga mutu sebesar $85 \%$.
\end{abstract}

Kata Kunci: Belimbing, Jaringan Syaraf Tiruan, Pengolahan Citra, Pemutuan.

\section{PENDAHULUAN}

Salah satu bentuk upaya penanganan pasca panen buah belimbing yang sering dilakukan oleh petani adalah dengan melakukan proses sortasi dan pemutuan terlebih dahulu sebelum dilakukannya pengiriman atau penjualan. Sortasi merupakan aktivitas pemisahan yang bertujuan untuk memisahkan bahan baku off grade dari bahan baku yang layak untuk diproses/diolah, sedangkan pemutuan merupakan aktivitas mengelompokkan bahan baku/produk yang telah disortasi dan diolah ke dalam kelaskelas atau kelompok tertentu berdasarkan karakteristik bahan yang digunakan sebagai faktor pemisah, sehingga masing-masing 
kelas seragam mutunya (Hariyadi dan Hartari, 2014).

Proses pemutuan yang dilakukan petani untuk buah belimbing di Indonesia umumnya masih menggunakan metode manual yaitu berdasarkan warna, ukuran, dan kerusakan. Metode ini dirasa belum cukup baik dikarenakan memiliki keterbatasan dari segi waktu, keragaman visual manusia, faktor kelelahan, dan perbedaan persepsi (penilaian manusia yang bersifat subjektif) tentang mutu dari produk yang bersangkutan. Berdasarkan hal tersebut maka perlu adanya metode lain yang dapat mengklasifikasikan buah belimbing lebih efektif dan efisien (Hendrawan dan Sumardi, 2005).

Salah satu pengembangan ilmu pengetahuan dan teknologi pertanian yang berkaitan dengan proses pemutuan tersebut adalah dengan menggunakan teknik pengolahan citra. Pengolahan citra merupakan bidang tersendiri yang mampu menangani data teks dan data citra berdasarkan sistem visual yang memiliki tingkat akurasi jauh lebih tinggi dari visual manusia (Ahmad, 2005).

Menurut Soedibyo (2006:2), pengolahan citra menggunakan sistem visual berdasarkan sensor elektro-optika mempunyai kemampuan yang lebih peka, tepat, dan obyektif daripada kemampuan visual manusia. Pengolahan citra mampu menyediakan sifat-sifat citra secara kuantitatif (variabel mutu citra) yang dibutuhkan sebagai input pengenalan pola. Namun, untuk meningkatkan keakuratan dalam penentuan mutu buah belimbing perlu adanya metode pendukung yaitu jarigan syaraf tiruan (JST). JST adalah sebuah konsep yang meniru cara kerja jaringan syaraf pada otak manusia dan dapat dilatih untuk mempelajari sesuatu. Menurut Wiharja dan Harjoko (2014), keuntungan dari metode JST adalah dapat membangun fungsi non linier dan hanya memerlukan data masukan dan keluaran tanpa mengetahui dengan jelas proses dalam jaringan. Hal ini cocok diterapkan pada data citra.

\section{Tujuan Penelitian}

Tujuan dari penelitian ini untuk menyusun sebuah program pemutuan buah belimbing manis menggunakan pengolahan citra digital berbasis jaringan syaraf tiruan serta mengetahui tingkat keakuratan program dalam menduga kelas mutu buah belimbing.

\section{METODOLOGI PENELITIAN}

\section{Alat}

Alat yang digunakan antara lain kamera CCD, kain tetron putih, 4 lampu TL 15 Watt, meja pengambilan gambar, perangkat komputer, software IC Capture 2.2, software Sharp Develop 4.2, software Ms. Excel, software Matlab 2014b, dan software Jasc Paint Shop Pro.

\section{Bahan}

Bahan yang digunakan dalam penelitian ini adalah belimbing dengan kelas mutu A, B, $\mathrm{C}$ dan Reject yang dimutukan secara manual terlebih dahulu. Total sampel 200 buah, terdiri atas 160 buah (40 buah per kelas mutu) untuk training dan 40 buah (10 per kelas mutu) untuk testing. Bahan didapatkan dari Desa Tamansari, Kecamatan Wuluhan, Kabupaten Jember.

\section{Prosedur Penelitian}

Prosedur penelitian meliputi persiapan alat dan bahan, pembuatan program pengolahan citra, pengolahan data, dan integrasi model JST ke program pengolahan citra.

\section{Persiapan Sampel}

Sampel buah belimbing diperoleh dengan cara membeli dari petani belimbing di Kabupaten Jember, Jawa Timur. Sampel kemudian dimutukan secara manual untuk memisahkan sampel kedalam empat kelas mutu, yaitu mutu A, mutu B, mutu $\mathrm{C}$, dan mutu Reject.

\section{Image Aquisition}

Proses ini dilakukan dengan penentuan jarak kamera dan penentuan proses penyinaran hingga didapatkan hasil citra belimbing yang mendekati aslinya, sedikit timbul bayangan, dan tidak ada cahaya berlebih yang mempengaruhi warna obyek. Metode penentuan image aquisition adalah trial and error. Skema pengaturan jarak kamera dan posisi lampu dapat dilihat pada Gambar 1 


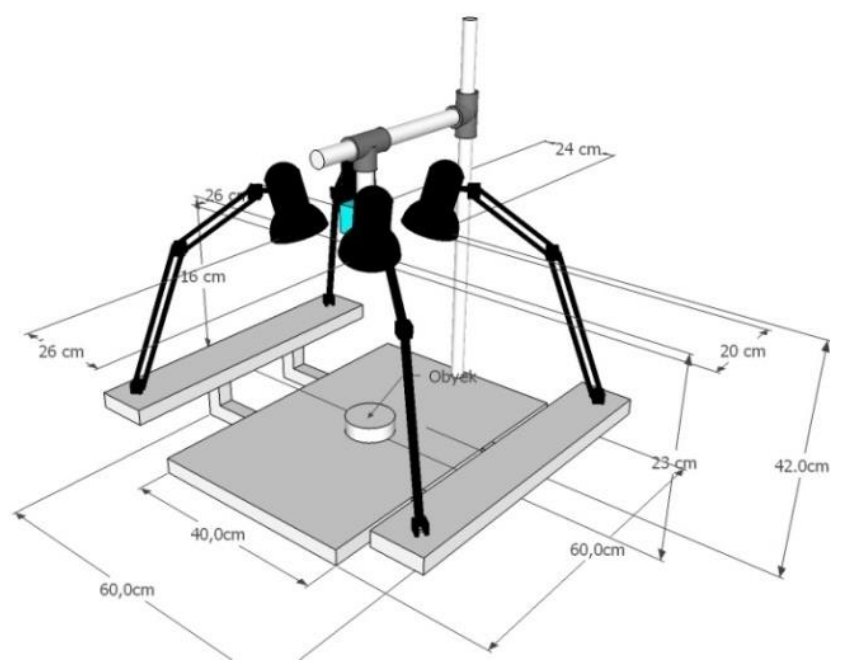

Gambar 1. Skema pengaturan jarak kamera dan posisi lampu

\section{Pengambilan Citra}

Pengambilan citra sampel dilakukan menggunakan perangkat meja pengambilan gambar dan kamera CCD. Metode pengambilan citra sampel dilakukan berdasarkan prosedur image aquisition yang telah dilakukan.

\section{Penentuan Variable Mutu Citra}

Kriteria mutu yang menentukan kualitas belimbing berdasarkan SNI 3211:2009 adalah warna, bentuk, ukuran, dan kerusakan. Pendugaan hubungan antara variabel mutu belimbing menurut SNI dan variabel mutu citra dijelaskan pada Tabel 1 . Tabel 1 Pendugaan hubungan antara variabel mutu belimbing manis menurut SNI dan variabel mutu citra

\begin{tabular}{ccc}
\hline NO & $\begin{array}{l}\text { Variabel mutu } \\
\text { Belimbing }\end{array}$ & Variabel mutu citra \\
\hline 1 & Ukuran & Area, tinggi, \\
& & dan lebar \\
2 & Warna & R, G, dan B \\
3 & Bentuk & Perimeter \\
4 & Kerusakan & Area cacat \\
\hline
\end{tabular}

Pembuatan Program Pengolahan Citra

Program pengolahan citra bertujuan melakukan analisa citra untuk menentukan parameter mutu berupa indeks warna buah, perimeter, area, tinggi, lebar, dan area cacat. Hasil analisa citra dari program ini di sajikan dalam bentuk file teks.
Analisis Statistik terhadap Variabel Mutu Citra

Hasil ekstraksi warna buah, perimeter, area, tinggi, lebar, dan area cacat dari citra perlu dianalisis dengan statistik untuk mengetahui korelasi antara parameter mutu citra dengan kriteria mutu sampel berdasarkan pemutuan manual. Ukuran statistik yang dipakai adalah rerata, standar deviasi, Q1 (kuartil pertama), median/ Q2 (kuartil kedua), Q3 (kuartil ketiga), nilai minimum dan nilai maksimum. Nilai-nilai parameter mutu yang telah ditabulasi, digambarkan dalam grafik boxplot. Berikut grafik boxplot ditampilkan pada Gambar 2.

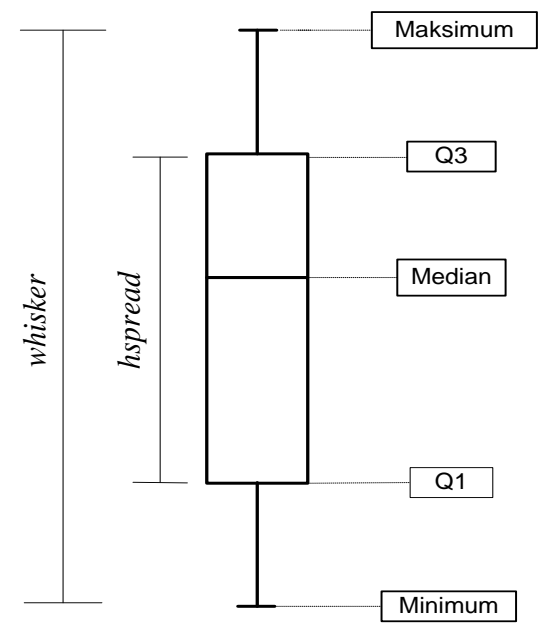

Gambar 2. Boxplot

\section{Penentuan Variasi Arsitektur Jaringan Syaraf Tiruan}

Variasi yang digunakan pada struktur JST adalah berdasarkan jumlah node lapisan tersembunyi. Dari variasi tersebut dianalisis karakteristiknya dan dipilih variasi terbaik yang memberikan akurasi tertinggi.

\section{Training Jaringan Syaraf Tiruan}

Sumber data yang digunakan dalam analisis JST adalah data hasil pengolahan citra, yang dibagi dalam dua bagian yaitu 160 data training dan 40 data testing. Data training memiliki nilai target yang dibagi menjadi 4 kelas mutu yaitu Mutu A, Mutu B, Mutu C dan Reject (RJ). Masingmasing data memiliki parameter mutu berupa area buah, tinggi buah, lebar buah, perimeter, area cacat, indeks warna $\mathrm{R}, \mathrm{G}$, dan B. Variabel mutu yang memiliki korelasi 
tinggi dengan kriteria mutu akan digunakan sebagai node pada input JST.

Pengujian dengan Propagasi Maju dan Pemilihan Arsitektur Terbaik

Propagasi maju dilakukan pada data testing menggunakan input yang dinormalisasikan. Nilai bobot yang telah dikoleksi pada training JST digunakan pada propagasi maju. Pasangan bilangan yang diperoleh (output) digunakan untuk mengidentifikasi kelas mutu belimbing. Fungsi yang diperoleh pada propagasi maju diintegrasikan dalam perangkat lunak pengolahan citra, sehingga perangkat lunak dapat mengidentifikasi kelas mutu belimbing.

\section{Pembuatan Program Pemutuan}

Program ini dibuat dengan cara mengintegrasikan bobot-bobot hasil pelatihan variasi JST terbaik dengan program pengolahan citra sehingga program dapat secara otomatis menduga kelas mutu berdasarkan nilai hasil pengolahan citra. Program ini menggunakan proses propagasi maju JST untuk pendugaan kelas mutu.

\section{Validasi}

Proses validasi dilakukan dengan cara menggunakan program pemutuan untuk menilai ketepatan prediksi kelas mutu yang dimiliki oleh 40 sampel yang telah khusus disiapkan untuk validasi. Hasil dari proses validasi ditampilkan dalam confusion matrix.
Jurnal AgriTechno. Vol. 12 (2): 121-130

https://doi.org/10.20956/at.vOi0.220

\section{Diagram Alir Penelitian}

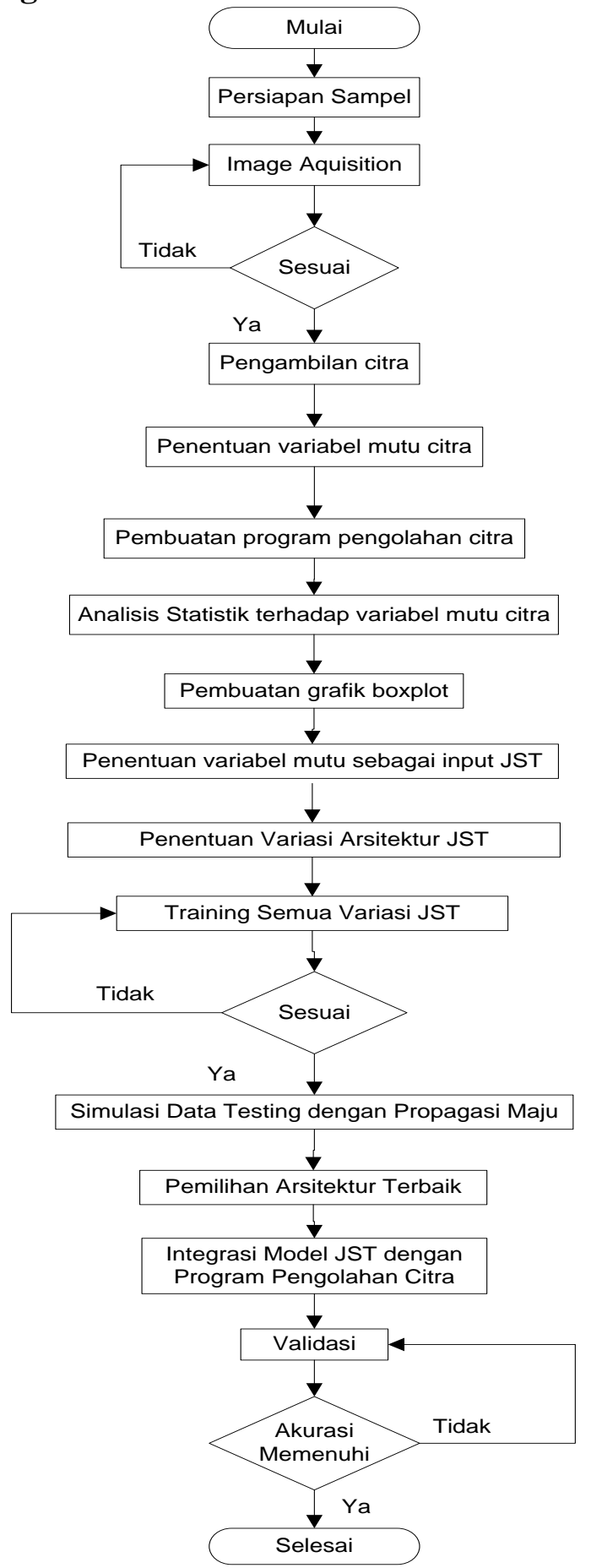

Gambar 3. Diagram Alir Proses

\section{HASIL DAN PEMBAHASAN}

\section{Program Pengolahan Citra Belimbing}

Gambar citra belimbing direkam menggunakan software IC Captured 6.5 yang dihubungkan dengan sebuah kamera Charge Couple Device (CCD) dengan resolusi $1024 \times 768$ piksel. Hasil pengambilan gambar disimpan dalam bentuk file dengan format BMP. Program pengolahan citra belimbing 
dibuat menggunakan software Sharp Develop 4.2. Program ini menghasilkan informasi nilai-nilai citra berupa area, tinggi, lebar, perimeter, area cacat, dan indeks warna RGB.

\section{Penentuan Nilai Batas Segmentasi (Threshold) Background}

Segmentasi background bertujuan untuk memisahkan citra obyek dengan background berdasarkan kriteria tertentu (perbedaan intensitas warna RGB). Perbedaan nilai RGB dijadikan nilai batas untuk membedakan obyek dan background. dengan mengambil masing-masing 50 titik sampel nilai RGB obyek dan background pada citra belimbing menggunakan software Jasc Paint Sop Pro 9. Sampel nilai ditabulasi dan dianalisis menggunakan grafik seperti tampak pada Gambar 4.

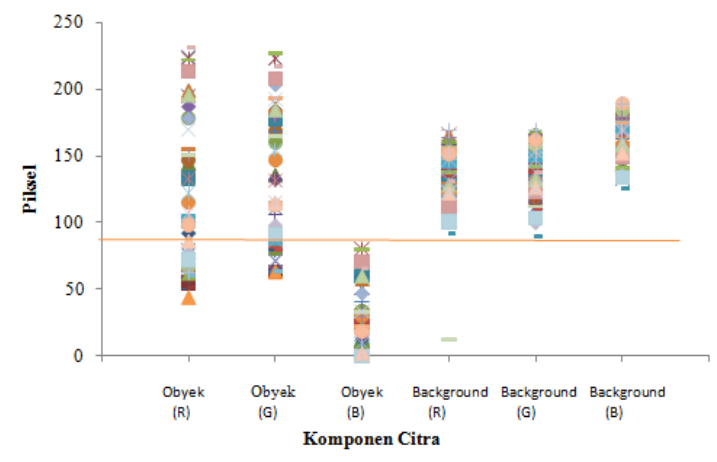

Gambar 4. Grafik RGB obyek dan background

Berdasarkan grafik pada Gambar 2. indeks warna B digunakan sebagai batas segmentasi obyek dan background dengan nilai $\mathrm{B}>80$. Indeks warna $\mathrm{R}$ dan $\mathrm{G}$ tidak dapat digunakan sebagai batas karena nilainya saling tumpanga tindih. Hasil proses thresholding obyek dan background dapat dilipat pada Gambar 5.

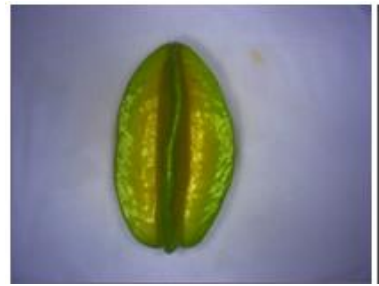

(a) Citra Asli;

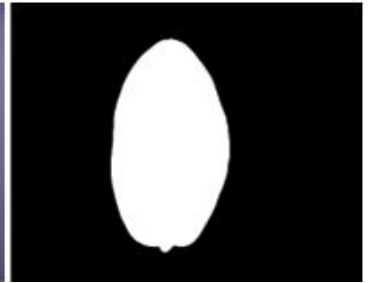

(b) Citra Biner
Gambar 5. Hasil thresholding background

\section{Penentuan Nilai Batas Segmentasi (Threshold) Area Cacat}

Segmentasi area cacat bertujuan untuk memisahkan citra area cacat dengan citra area normal berdasarkan kriteria tertentu (perbedaan intensitas warna RGB). Proses penentuan thresholding area cacat sama dengan penentuan treshold background, hanya berbeda pada titik pengambilan sampelnya (titk area yang dinggap cacat dan area normal). Grafik sampel nilai RGB antara Area cacat dan area normal (obyek) dapat dilihat pada Gambar 6.

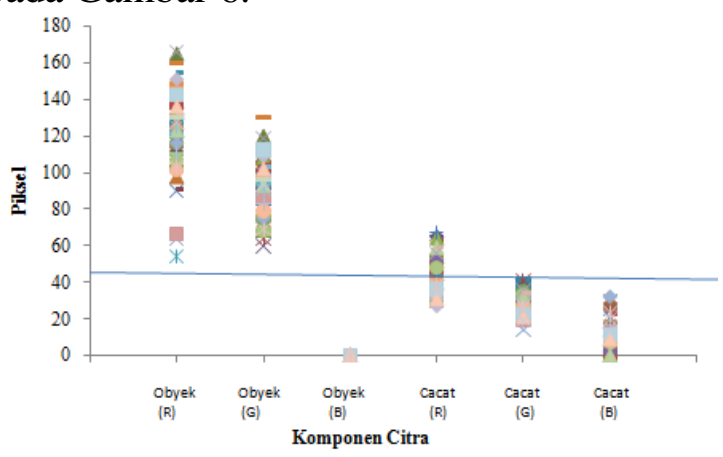

Gambar 6. Grafik RGB obyek dan area cacat Berdasarkan grafik pada Gambar 2. indeks warna $\mathrm{G}$ digunakan sebagai batas segmentasi obyek dan area cacat dengan nilai $\mathrm{G}<41$. Indeks warna $\mathrm{R}$ dan $\mathrm{B}$ tidak dapat digunakan sebagai batas karena nilainya saling tumpang tindih. Hasil operasi threshod antara obyek dan area cacat dapat di lihat pada Gambar 7.

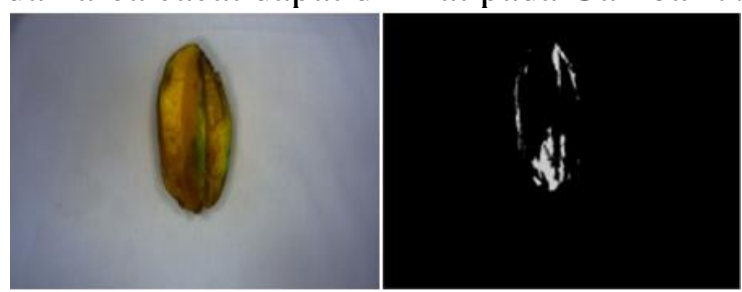

$\begin{array}{ll}\text { (a) Citra asli } & \text { (b) Citra area cacat }\end{array}$

Gambar 7. Hasil operasi thresholding area cacat

\section{Ekstraksi Citra}

Menurut Kusumaningsih (2009), salah satu teknik untuk mendapatkan pola suatu citra adalah dengan melakukan ekstraksi ciri citra. Ekstraksi ciri dilakukan berdasarkan isi visual dari citra yaitu bentuk, warna dan tekstur. Ekstraksi citra bertujuan untuk memperoleh nilai nilai variabel citra melalui operasi tertentu pada piksel pembentuk citra. Proses ekstraksi citra untuk mendapatkan nilai-nilai variabel mutu citra sebagai berikut :

a. Menentukan area buah dengan menghitung jumlah piksel berwarna putih pada citra biner hasil segmentasi.

b. Penentuan tinggi buah diperoleh dengan menghitung panjang piksel berwarna putih secara vertikal pada citra biner 
c. Penentuan lebar buah diperoleh dengan menghitung panjang piksel berwarna putih secara horizontal pada citra biner

d. Penentuan nilai perimeter buah belimbing manis dihitung dengan menjumlahkan piksel perbatasan antara obyek dengan background pada citra biner

e. Penentuan area cacat belimbing manis diperoleh melalui proses binerisasi dengan fungsi threshold pada sinyal RGB. Perhitungan area cacat dilakukan dengan menjumlahkan semua piksel yang berwarna abu-abu pada citra area cacat.

f. Penentuan nilai RGB dilakukan dengan menghitung rata-rata nilai indeks warna merah, hijau, dan biru pada area buah tanpa cacat. Nilai $R, G$ dan B area buah yang cacat tidak perlu dihitung karena nilai RGB ini dimaksudkan untuk mengetahui warna kulit buahnya.

\section{Analisis Statistik Terhadap Variabel Mutu Citra}

Hasil proses ekstraksi variabel mutu citra diolah dengan MS Excel 2007 dengan tujuan untuk mendapatkan ukuran statistik masingmasing variabel berupa rerata, standar deviasi, Q1, Q2, Q3, nilai minimum, dan nilai maksimum. Untuk mempermudah proses analisis data, ukuran statistik variabel mutu citra ditampilkan dalam grafik boxplot. Melalui proses ini akan diketahui korelasi antara variabel mutu citra dengan kriteria mutu belimbing manis berdasarkan pemutuan manual. Berikut ini penjabaran ukuran statistik masing-masing kelas mutu hasil ekstraksi variabel mutu citra pada data sejumlah 160 sampel belimbing manis.

Area

Berikut merupakan grafik boxplot area yang ditampilkan pada Gambar 8.

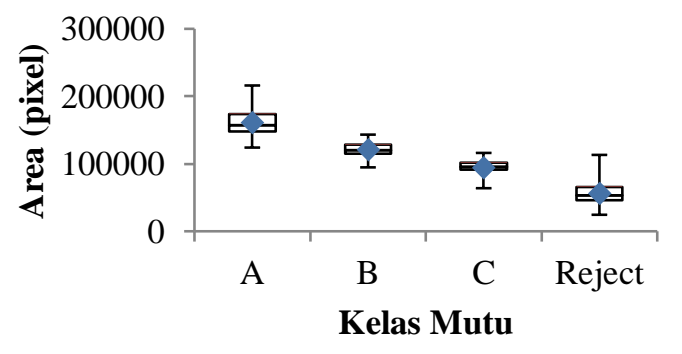

Gambar 8. Grafik boxplot area

Berdasarkan grafik boxplot pada Gambar 8. sebaran nilai area pada kelas mutu A, B, C, dan Reject tidak terdapat data yang saling tumpang tindih. Grafik tersebut menunjukkan bahwa nilai area dari kelas mutu A, B, C dan Reject semakin menurun, hal ini sesuai dengan pemutuan manual yang dilakukan berdasarkan ukuran buah, semakin besar kelas mutu buah semakin besar pula nilai areanya.

\section{Tinggi}

Berikut merupakan grafik boxplot tinggi yang ditampilkan pada Gambar 9.

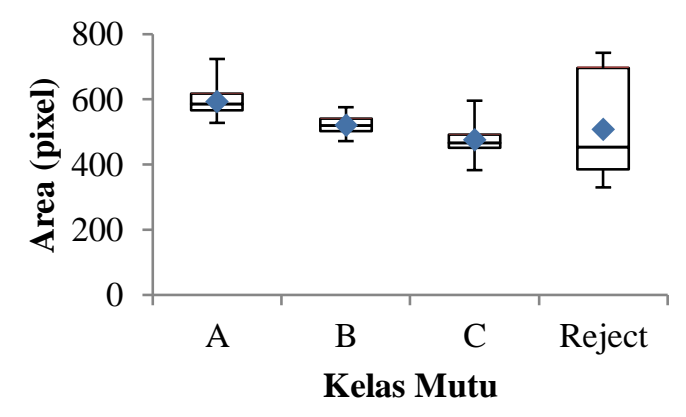

Gambar 9. Grafik boxplot tinggi

Berdasarkan grafik boxplot pada Gambar 9. sebaran nilai tinggi pada kelas mutu A, B, $\mathrm{C}$, dan Reject terdapat data yang saling tumpang tindih. Data nilai sebaran A, B, C cenderung mengalami penurunan, kecuali pada kelas mutu Reject yang memiliki nilai lebih tinggi dari mutu lain. Kenaikan nilai pada mutu Reject dikarenakan pada beberapa sampel foto mengalami kesalahan deteksi program. Kesalahan deteksi tersebut terjadi karena ada beberapa file sampel (foto) mutu Reject yang kurang sesuai sehingga menyebabkan nilainya pun tidak menentu.

\section{Lebar}

Berikut merupakan grafik boxplot lebar yang ditampilkan pada Gambar 10.

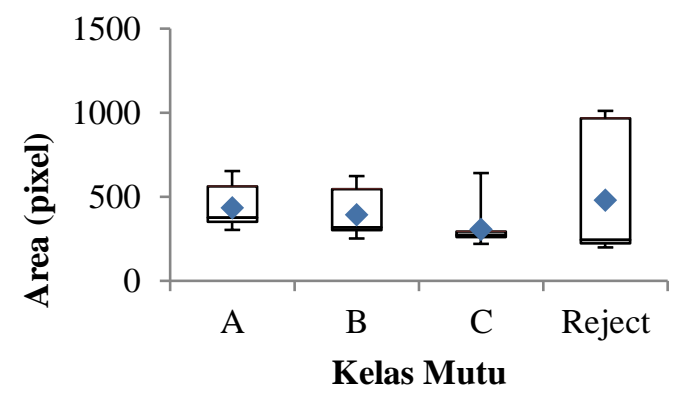

Gambar 10. Grafik boxplot lebar

Berdasarkan grafik boxplot pada Gambar 10. sebaran nilai lebar pada kelas mutu A, B, $\mathrm{C}$, dan Reject saling tumpang tindih. Sama halnya dengan variabel tinggi, kenaikan nilai 
pada mutu Reject juga terjadi pada variabel mutu lebar, hal ini dikarenakan pada beberapa sampel foto mutu Reject mengalami kesalahan deteksi program. Berdasarkan grafik diatas dapat disimpulkan bahwa berdasarkan pemutuan secara manual, lebar buah belimbing dari setiap mutu hampir sama, hal ini karena pengelompokan kelas mutu secara manual yang dilakukan kurang ketat.

\section{Perimeter}

Berikut merupakan grafik boxplot perimeter yang ditampilkan pada Gambar 11 .

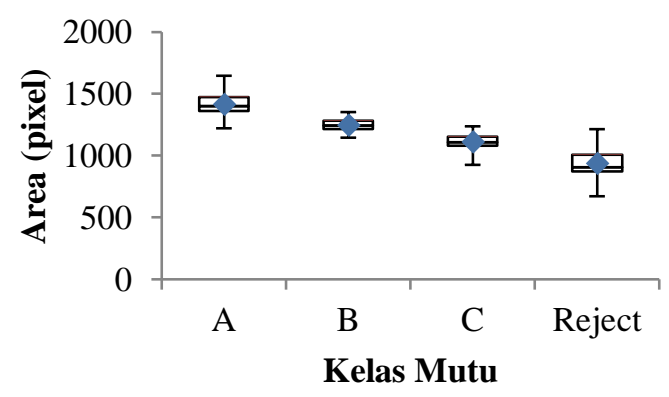

Gambar 11. Grafik boxplot perimeter

Berdasarkan grafik boxplot pada Gambar 11. sebaran nilai perimeter pada kelas mutu A, B, C, dan Reject tidak terdapat data yang saling tumpang tindih. Data nilai sebaran kelas mutu A sampai Reject cenderung mengalami penurunan. Nilai perimeter semakin kecil karena pada kenyataanya berdasarkan pemutuan manual yang dilakukan, ukuran lingkar buah (keliling) belimbing mulai dari kelas mutu A, B, C dan Reject juga semakin kecil.

\section{e. Area cacat}

Berikut merupakan grafik boxplot area cacat yang ditampilkan pada Gambar 12.

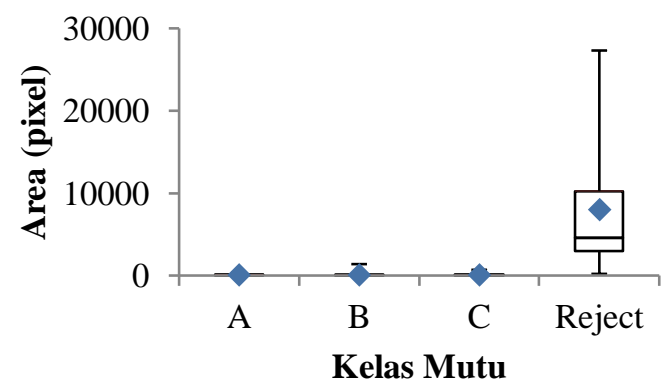

Gambar 12. Grafik boxplot area cacat
Berdasarkan boxplot pada Gambar 12. data sebaran nilai cacat pada mutu A hingga mutu C saling tumpang tindih kecuali box pada mutu Reject yang memiliki nilai cacat terbesar. Area cacat pada mutu Reject memiliki range nilai yang sangat besar, dibandingkan kelas mutu lain. Hal ini sesuai dengan pemutuan manual yang dilakukan, dimana kelas mutu Reject adalah buah yang mimiliki area cacat lebih besar dari kelas utu lain.

\section{Indek warna merah $(\mathbf{R})$}

Berikut merupakan grafik boxplot indeks warna merah yang ditampilkan pada Gambar 13.

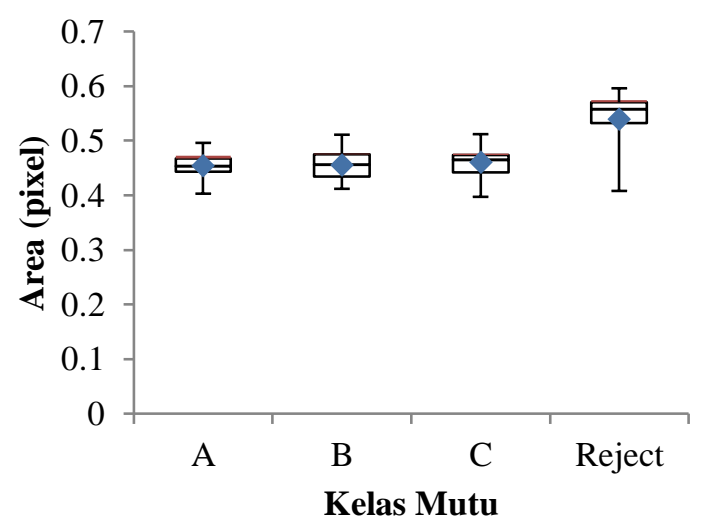

Gambar 13. Grafik boxplot indeks warna merah

Berdasakan Gambar 13. sebaran nilai indeks warna merah pada setiap kelas mutu A hingga $\mathrm{C}$ hampir sama dan mengalami tumpang tindih. Namun sebaran nilai pada kelas mutu Reject lebih tinggi dibandingkan kelas mutu lain. Hal ini karena kelas mutu Reject memilki warna kuning kemerahan yang cukup dominan dibandingkan dengan kelas mutu lain. Sesuai dengan konsep model warna RGB dimana warna kuning adalah kombinasi antara warna merah dan hijau. Semakin terang warna kulit buah, maka semakin tinggi nilai warna $\mathrm{R}$.

Indeks warna hijau (G)

Berikut merupakan grafik boxplot indeks warna hijau yang ditampilkan pada Gambar 14. 


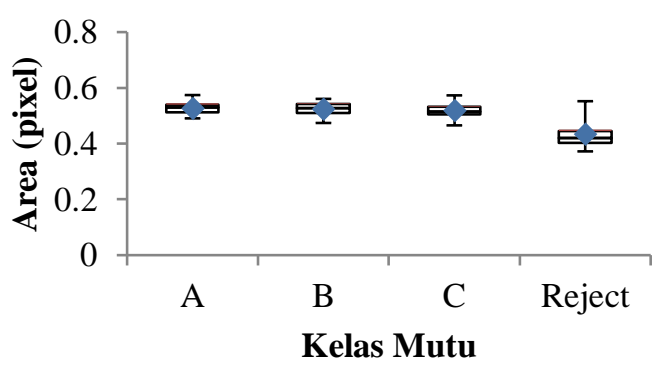

Gambar 14. Grafik boxplot indeks warna hijau

Berdasarkan Gambar 14. sebaran nilai indeks warna hijau pada setiap kelas mutu A hingga $\mathrm{C}$ hampir sama dan mengalami tumpang tindih. Namun sebaran nilai pada kelas mutu Reject lebih rendah dibandingkan kelas mutu lain. Kulit buah pada kelas mutu A hingga $C$ rata-rata berwarna hijau, hal ini menyebabkan nilai warna $G$ pada kelas mutu A,B, dan $\mathrm{C}$ lebih tinggi.

\section{Indeks warna Biru}

Berikut merupakan grafik boxplot indeks warna merah yang ditampilkan pada Gambar 15.

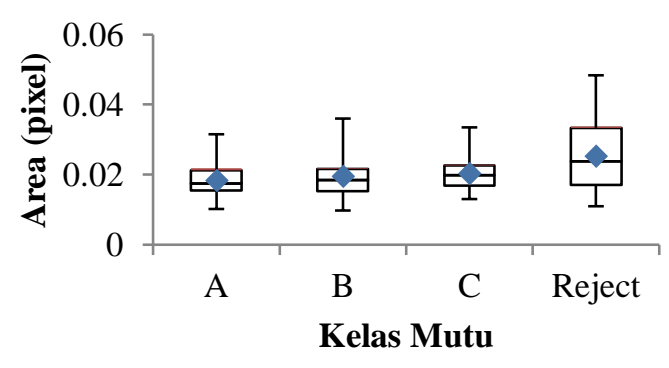

Gambar 15. Grafik boxplot indeks warna biru Selain indeks warna merah dan hijau, kulit buah belimbing juga memiliki nilai indeks warna biru meskipun kadar nilainya sedikit jika dibandingkan dengan indeks warna merah dan hijau. Berdasarkan grafik boxplot pada Gambar 15. nilai sebaran variabel indeks warna biru pada semua kelas mutu mengalami tumpang tindih. Hal ini terjadi karena semua kelas mutu memiliki kisaran indeks warna biru yang hampir sama.

\section{Penentuan Variasi Jaringan Syaraf Tiruan Terbaik}

Hasil analisis statistik variabel mutu citra buah belimbing menunjukkan semua variabel mutu dapat digunakan sebagai input JST, meskipun ada beberapa variabel yang tumpang tindih, variabel yang tumpang tindih tersebut kemungkinan masih dapat digunakan sebagai input JST. Penentuan kriteria variasi arsitektur JST adalah sebbagai berikut:

a. normalisasi data menggunakan metode minmax (kisaran $[-0,9 ; 0,9]$ )

b. Hidden layer menggunakan 10 dan 15 node

c. jumlah variasi target output 2 target

d. nilai laju pembelajaran dan momentum sebesar 0,8 dan 0,2

e. Penentuan penghentian iterasi berdasarkan hasil trial dan error dengan jumlah iterasi 100.000

f. MSE (mean square error) sebesar 0,05

Berikut merupakan Enam variasi JST yang dibuat dan hasil dari pelatihan keenam variasi mulai dari J1 sampai dengan J6 ditampilkan pada Tabel 2 .

Tabel 2. Hasil pelatihan keenam variasi JST

\begin{tabular}{clcc}
\hline & \multicolumn{1}{c}{ Variasi } & Iterasi & Gradien \\
\hline 10 & 8 Input Layer & 20784 & 0,002492 \\
& 7 Input Layer tanpa & 30411 & 0,0036988 \\
& lebar & & \\
& 6 Input Layer tanpa & 100000 & 0,0042484 \\
& lebar dan b & & \\
15 & 8 Input Layer & 25096 & 0,0040067 \\
& 7 Input Layer tanpa & 18917 & 0,0057297 \\
& lebar & & \\
& 6 Input Layer tanpa & 35462 & 0,0042386 \\
& lebar dan b & & \\
\hline
\end{tabular}

Pemilihan Variasi JST terbaik dilakukan dengan melakukan propagasi maju pada data testing yang berjumlah 40 data. Variasi terbaik adalah variasi jaringan yang menunjukkan persentase kesesuain pendugaan target paling tinggi. Berikut merupakan hasil dari propagasi maju data testing pada keempat variasi JST ditampilkan pada Tabel 3.

Tabel 3. Hasil dari propagasi maju data testing pada keempat variasi JST

\begin{tabular}{cccccc}
\hline Variasi & \multicolumn{4}{c}{ Kesesuaian Target } & Jumlah \\
\cline { 2 - 5 } JST & $\mathrm{A}$ & $\mathrm{B}$ & $\mathrm{C}$ & Reject & Benar \\
\hline J1 & 10 & 4 & 8 & 9 & 31 \\
Persentase & 100 & 50 & 80 & 90 & 78 \\
J2 & 10 & 5 & 8 & 9 & 32 \\
Persentase & 100 & 50 & 80 & 90 & 80 \\
J3 & 8 & 7 & 7 & 8 & 30 \\
Persentase & 80 & 70 & 70 & 80 & 75 \\
J4 & 9 & 8 & 6 & 8 & 31 \\
Persentase & 90 & 80 & 60 & 80 & 78 \\
J5 & 10 & 5 & 2 & 9 & 26 \\
Persentase & 100 & 50 & 20 & 90 & 65 \\
J6 & 10 & 7 & 5 & 9 & 31 \\
Persentase & 100 & 70 & 50 & 90 & 78 \\
\hline
\end{tabular}


Tabel 3. menunjukkan hasil dari propagasi maju pada setiap variasi. Persentase kesesuaian pendugaan target terbaik adalah variasi J2 yaitu variasi dengan penggunaan 7 input variabel (tanpa penggunaan variabel lebar) dan 10 node hidden layer dengan hasil persentase sebesar $80 \%$.

\section{Integrasi Program Pengolahan Citra dengan JST}

Pelatihan JST menggunakan Matlab menghasilkan bobot-bobot yang akan digunakan dalam program pemutuan. Bobot yang dihasilkan dari variasi terbaik nantinya digunakan sebagai input program pada fungsi propagasi maju (feedfordward), sehingga program dapat menduga kelas mutu belimbing manis secara otomatis berdasarkan nilai variabel mutu citra. Berikut merupakan proses integrasi program pengolahan citra dengan pemodelan JST

\section{Normalisasi data input}

Sumber data yang akan digunakan sebagai input JST harus dinormalkan (normalisasi minmax (kisaran $[-0,9 ; 0,9])$ terlebih dahulu. Normalisasi data bertujuan untuk memudahkan identifikasi obyek dengan relasinya.

\section{Propagasi maju}

Fungsi propagasi maju diberikan pada data input yang telah dinormalkan dengan nilai bobot dari variasi J2. Fungsi aktivasi yang yaitu fungsi aktivasi sigmoid bipolar hyperbolic tangent. Nilai output yang dihasilkan berupa dua buah bilangan bipolar. Berikut persamaan fungsi hyperbolic tangent:

\section{Pendugaan mutu}

$$
y=f(x)=\frac{1-e^{-2 x}}{1+e^{-2 x}}
$$

Nilai bilangan bipolar hasil propagasi maju akan ditransformasikan dalam kelas mutu belimbing manis. Berikut transformasi nilai hasil propagasi maju menjadi kelas mutu belimbing manis ditampilkan pada Tabel 4 .

Tabel 4. Definisi output

\begin{tabular}{|c|c|c|}
\hline \multicolumn{2}{|c|}{ Output } & \multirow{2}{*}{ Kelas Mutu } \\
\hline Y1 & Y2 & \\
\hline$>0$ & $>0$ & A \\
\hline$>0$ & $<0$ & B \\
\hline$<0$ & $>0$ & C \\
\hline$<0$ & $<0$ & Reject \\
\hline
\end{tabular}

Program pemutuan belimbing manis memiliki tambahan text box "Mutu" yang berguna untuk menampilkan hasil pendugaan kelas mutu citra belimbing manis yang diolah. Informasi kelas mutu hasil pendugaan tersebut nantinya ditambahkan pada file teks hasil program, informasi tersebut nantinya dapat digunakan untuk proses validasi program. Berikut merupakan tampilan program pemutuan belimbing manis yang ditunjukkan pada Gambar 16.

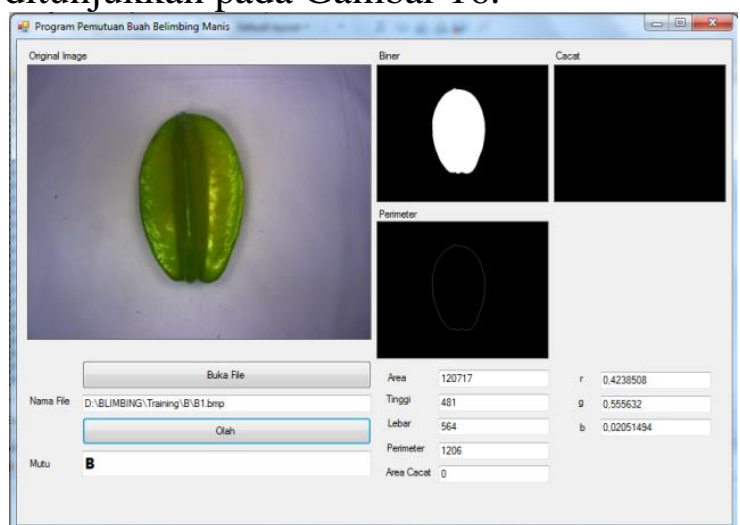

Gambar 16. Tampilan program pemutuan belimbing manis

\section{Validasi Program Pemutuan Belimbing Manis}

Validasi program pemutuan dilakukan untuk mengetahui nilai akurasi kinerja program dalam pendugaan mutu belimbing manis pada 40 data testing. Hasil pendugaan mutu ditampilkan dalam confussion matrix untuk mempermudah analisis pada masingmasing kelas mutu. Berikut confussion matrix hasil validasi program pemutuan belimbing manis ditampilkan pada Tabel 5.

Tabel 5. Hasil analisis confusion matrix

\begin{tabular}{|c|c|c|c|c|c|c|c|c|}
\hline \multirow{2}{*}{\multicolumn{2}{|c|}{ Kelas Mutu }} & \multicolumn{4}{|c|}{ Prediksi } & \multirow{2}{*}{$\begin{array}{l}\text { Total } \\
\text { baris }\end{array}$} & \multirow{2}{*}{$\begin{array}{c}\text { Akurasi } \\
\text { produksi } \\
(\%)\end{array}$} & \multirow{2}{*}{$\begin{array}{l}\text { Kesalahan } \\
\text { omisi (\%) }\end{array}$} \\
\hline & & A & B & $\mathrm{C}$ & $R J$ & & & \\
\hline \multirow{4}{*}{ Aktual } & A & 10 & 0 & 0 & 0 & 10 & 100 & 0 \\
\hline & B & 1 & 8 & 1 & 0 & 10 & 80 & 20 \\
\hline & $\mathrm{C}$ & 0 & 1 & 7 & 2 & 10 & 70 & 30 \\
\hline & $R J$ & 0 & 0 & 1 & 9 & 10 & 90 & 10 \\
\hline \multicolumn{2}{|c|}{ Total } & 11 & 9 & 9 & 11 & 40 & 40 & \\
\hline \multicolumn{2}{|c|}{$\begin{array}{c}\text { Akurasi user } \\
(\%)\end{array}$} & 90,91 & 88,89 & 77,78 & 81,82 & & & \\
\hline \multicolumn{2}{|c|}{$\begin{array}{l}\text { Kesalahan } \\
\text { komisi }(\%)\end{array}$} & 9,09 & 11,11 & 22,22 & 18.18 & & & \\
\hline \multicolumn{2}{|c|}{ Akurasi Total } & $85 \%$ & & & & & & \\
\hline
\end{tabular}

Berdasarkan Tabel 5. diketahui tingkat akurasi produksi kelas mutu A, B, C, dan Reject beragam. Akurasi pendugaan tertinggi 
terdapat pada kelas mutu A dengan akurasi produksi dan user masing - masing sebesar $100 \%$ dan $90.91 \%$. Sementara pendugaan dengan tingkat akurasi produksi dan user terendah terdapat pada kelas mutu $\mathrm{C}$ masing masing sebesar $70 \%$ dan $77,78 \%$. Kesalahan pendugaan terjadi karena terdapat data nilainilai variabel mutu citra yang saling tumpang tindih. Nilai yang saling tumpang tindih mengindikasikan proses pemutuan yang dilakukan oleh petani memiliki standar yang kurang ketat. Hasil validasi program pemutuan belimbing manis menunjukkan tingkat akurasi total program sebesar $85 \%$.

\section{KESIMPULAN}

Kesimpulan dari penelititan ini yakni:

1. Proses pemutuan buah belimbing dapat dilakukan dengan menggunakan pengolahan citra digital berbasis jaringan syaraf tiruan dengan variabel area, tinggi, perimeter, area cacat, dan indeks warna RGB sebagai inputnya.

2. Variasi arsitektur yang digunakan adalah variasi dengan 7 input variabel (tanpa lebar) dan 10 node hidden layer dengan normalisasi minmax.

3. Hasil validasi program menunjukkan bahwa program pengolahan citra untuk pemutuan buah belimbing manis memiliki tingkat akurasi sebesar $85 \%$.

\section{DAFTAR PUSTAKA}

Ahmad, U. 2005. Pengolahan Citra Digital \& Teknik Pemrogramannya. Yogyakarta: Graha Ilmu

Hariyadi, P. dan Hartari, A. 2014. Pembersihan, Sortasi, dan Grading.

Hendrawan, S dan Sumardi, H.S. 2005. Pengkajian Karakteristik Mutu Buah Belimbing Manis (Averrhoa Carambola L.) dengan Teknik Pengolahan Citra. 6(2): 131-132. Jurnal Teknologi Pertanian.

Kusumaningsih, I. 2009. Ekstraksi Ciri Warna, Bemtuk, dan Tekstur Untuk Temu Kembali Citra Hewan. Tidak Diterbitkan. Skripsi. Bogor: Institut Pertanian Bogor (IPB).
Jurnal AgriTechno. Vol. 12 (2): 121-130

https://doi.org/10.20956/at.v0i0.220

Soedibyo, D. W. 2006. Pemutuan Edamame (Glycine Max (L) Merrill.) dengan Menggunakan Pengolahan Citra (Image Processing). Tidak Diterbitkan. Tesis. Bogor: Institut Pertanian Bogor (IPB).

Wiharja, Y.P. dan Harjoko, A. 2014. Pemrosesan Citra Digital untuk Klasifikasi Mutu Buah Pisang Menggunakan Jaringan Saraf Tiruan. IJEIIS. 4(1): 57-58 